\title{
Extraction of Zinc from Smithsonite by Ammonia Leaching
}

\author{
Deniz Talan, M. Ümit Atalay, N. Emre Altun \\ Middle East Technical University, Mining Engineering Department \\ Ankara, Turkey \\ dtalan@metu.edu.tr; atalay@metu.edu.tr; ealtun@metu.edu.tr
}

\begin{abstract}
In this study, an ore taken from Kayseri region of Turkey was used. Characterization studies showed that the run-of mine ore is rich in oxide minerals, cerussite $\left(\mathrm{PbCO}_{3}\right)$ and smithsonite $\left(\mathrm{ZnCO}_{3}\right)$. The aim of the study was extraction of zinc from smithsonite by ammonia leaching on cerussite flotation tailings. Initial lead and zinc grades of the ore were $13.31 \%$ and $27.86 \%$, respectively. As a result of a series of cerussite flotation tests, a lead concentrate containing $63.25 \% \mathrm{~Pb}$ was produced with $82.76 \%$ recovery. After that, tailing of flotation was treated with ammonia $\left(\mathrm{NH}_{3}\right)$ to extract zinc. For that purpose, $5 \mathrm{M}$ and $7 \mathrm{M}$ of $\mathrm{NH}_{3}$ solutions were used for 30 minutes, 1 hour, 3 hours, 6 hours and 12 hours. In consequence of the leaching experiments, the highest extraction rate was obtained as $76.66 \%$ using $7 \mathrm{M} \mathrm{NH}_{3}$ solution with 12 hours of treatment.
\end{abstract}

Keywords: Smithsonite, ammonia, leaching

\section{Introduction}

Lead and zinc are two of the most widely used commodities and have a big importance for industry. Even though their major sources are sulfides, finding new sources for production of lead and zinc concentrates as an alternative for depleting sulfide sources is a matter of issue (Ejtemaei et al, 2014). Cerussite and smithsonite are the most abundant non-sulfide minerals of lead and zinc and they have a considerable potential to produce lead and zinc concentrates (Moradi \& Monhemius, 2011; Ma et al, 2011; Abkhoshk et al, 2014). Most commonly, hydrometallurgical processes or froth flotation are performed for concentration of cerussite and smthisonite (Gupta \& Yan, 2006; Abkhoshk et al, 2014). Even though flotation of oxide minerals is quite hard due to consumption of excessive amounts of flotation reagents, lower selectivity and surface coating problems, flotation is still applicable and widely used method (Şentürk, 1987; Lan et al, 2013). Although it requires more time, hydrometallurgy is more adventageous especially for low grade ores and finely disseminated particles (Habashi, 1970; Meng \& Han, 1996).

Despite in many studies possibility of smithsonite flotation has been proven (Şentürk et al, 1993; Fa et al, 2005; Ejtemaei et al, 2011; Mehdilo et al, 2014), in some cases flotation become less viable by virtue of complex structure of the mineral. At that case, leaching may be preferred. Sulfuric acid is used commonly as leaching reagent for extraction of oxide zinc minerals, but due to silica gel forming, usage of new chemicals such as ammonia and its salts is gaining importance (Ju et al, 2005; Liu et al, 2012). Several studies were carried out to investigate the leachability of zinc oxide using ammonia and ammonium salts (Ju et al, 2005; Moghaddam et al, 2005; Wang et al, 2008; Ma et al, 2011). Main conclusions of these studies are ammonia can be used as a leaching reagent for extraction of $\mathrm{Zn}$ but concentration of the reagent, leaching duration, particle size of the test sample and temperature are some main parameters that need to be controlled for a successive process.

Turkey has a lot of oxide zinc sources mainly distributed in Central Anatolia (SOP, 2011) and the aim of this study is to beneficiation of an ore taken from Central Anatolia, containing smithsonite with $28.31 \% \mathrm{Zn}$ by agitated ammonia leaching by investigating the effect of reagent concentration and leaching duration on $\mathrm{Zn}$ extraction rate. 


\section{Experimental}

\subsection{Material}

The ore used throughout the study was collected from Kayseri-Develi region of Turkey where oxide lead and zinc minerals are predominant. Characterization studies were completed using polorized microscope, X-Ray Fluorescence (XRF) and X-Ray Diffraction (XRD) analysis. Cerussite $\left(\mathrm{PbCO}_{3}\right)$ and smithsonite $\left(\mathrm{ZnCO}_{3}\right)$ were identified as predominant species with $13.59 \% \mathrm{~Pb}$ and $28.31 \% \mathrm{Zn}$ grade. Hemimorphite $\left(\mathrm{Zn}_{4}\left(\mathrm{Si}_{2} \mathrm{O}_{7}\right)(\mathrm{OH})_{2} \cdot \mathrm{H}_{2} \mathrm{O}\right)$, limonite $\left(\mathrm{Fe}(\mathrm{OH})_{3}\right)$, calcite $\left(\mathrm{CaCO}_{3}\right)$ and dolomite $\left(\mathrm{CaMg}\left(\mathrm{CO}_{3}\right)_{2}\right)$ were also present as accessory minerals. Formations of galena $(\mathrm{PbS})$, sphalerite $(\mathrm{ZnS})$ were also seen from microsocopic image of the sample but most of galena and sphalerite particles were transforming to cerussite and smithsonite. Concentrations of major constituents obtained from $\mathrm{XRF}$ analysis is presented in Table 1.

Table 1: Chemical analysis result of run-of mine ore.

\begin{tabular}{|c|c|c|c|c|c|c|c|c|}
\hline Pb (\%) & Zn (\%) & Ag (ppm) & Al (\%) & Ca (\%) & Fe (\%) & Mg (\%) & Cu (ppm) & Si (\%) \\
\hline 13.31 & 27.86 & 89 & 0.49 & 2.57 & 5.41 & 0.78 & 9.4 & 5.28 \\
\hline
\end{tabular}

Particle size of the representative sample determined by sieve analysis and metal distribution of the representative sample is determined using Atomic Absroption Spectroscopy (AAS). The results of particle size analysis together with metal distribution analysis are provided in Table 2. Zinc grade is decreasing related to particle size. On the other hand lead grade is increasing with decreasing particle size up to $210 \mu \mathrm{m}$.

Table 2: Particle size and metal distribution of test sample.

\begin{tabular}{|c|c|c|c|c|c|c|}
\hline P. Size $(\boldsymbol{\mu m})$ & \% Wt. & $\begin{array}{c}\text { Cum. U/S } \\
(\boldsymbol{\%})\end{array}$ & $\mathbf{P b}(\boldsymbol{\%})$ & $\mathbf{Z n}(\boldsymbol{\%})$ & $\begin{array}{c}\text { Pb Distr. } \\
(\boldsymbol{\%})\end{array}$ & $\begin{array}{c}\text { Zn Distr. } \\
(\boldsymbol{\%})\end{array}$ \\
\hline 1300 & 27,76 & 100,00 & 12,40 & 30,00 & 25,87 & 29,89 \\
\hline 1168 & 23,98 & 72,24 & 13,45 & 29,60 & 24,24 & 25,47 \\
\hline 600 & 5,42 & 48,26 & 14,60 & 28,10 & 5,95 & 5,47 \\
\hline 417 & 4,24 & 42,84 & 15,50 & 27,90 & 4,94 & 4,25 \\
\hline 295 & 7,03 & 38,60 & 16,60 & 27,70 & 8,77 & 6,99 \\
\hline 210 & 2,37 & 31,56 & 17,15 & 26,60 & 3,05 & 2,26 \\
\hline 150 & 5,02 & 29,20 & 15,05 & 24,70 & 5,68 & 4,45 \\
\hline 106 & 4,10 & 24,17 & 15,95 & 25,70 & 4,91 & 3,78 \\
\hline 74 & 20,08 & 20,08 & 11,00 & 24,20 & 16,59 & 17,44 \\
\hline & 100,00 & & $\mathbf{1 3 , 3 1}$ & $\mathbf{2 7 , 8 6}$ & 100,00 & 100,00 \\
\hline
\end{tabular}

Graphical representation of metal distributions is given in Fig. 1. From the figure, it can be stated that both lead and zinc were distributed significantly in coarse size fractions. 


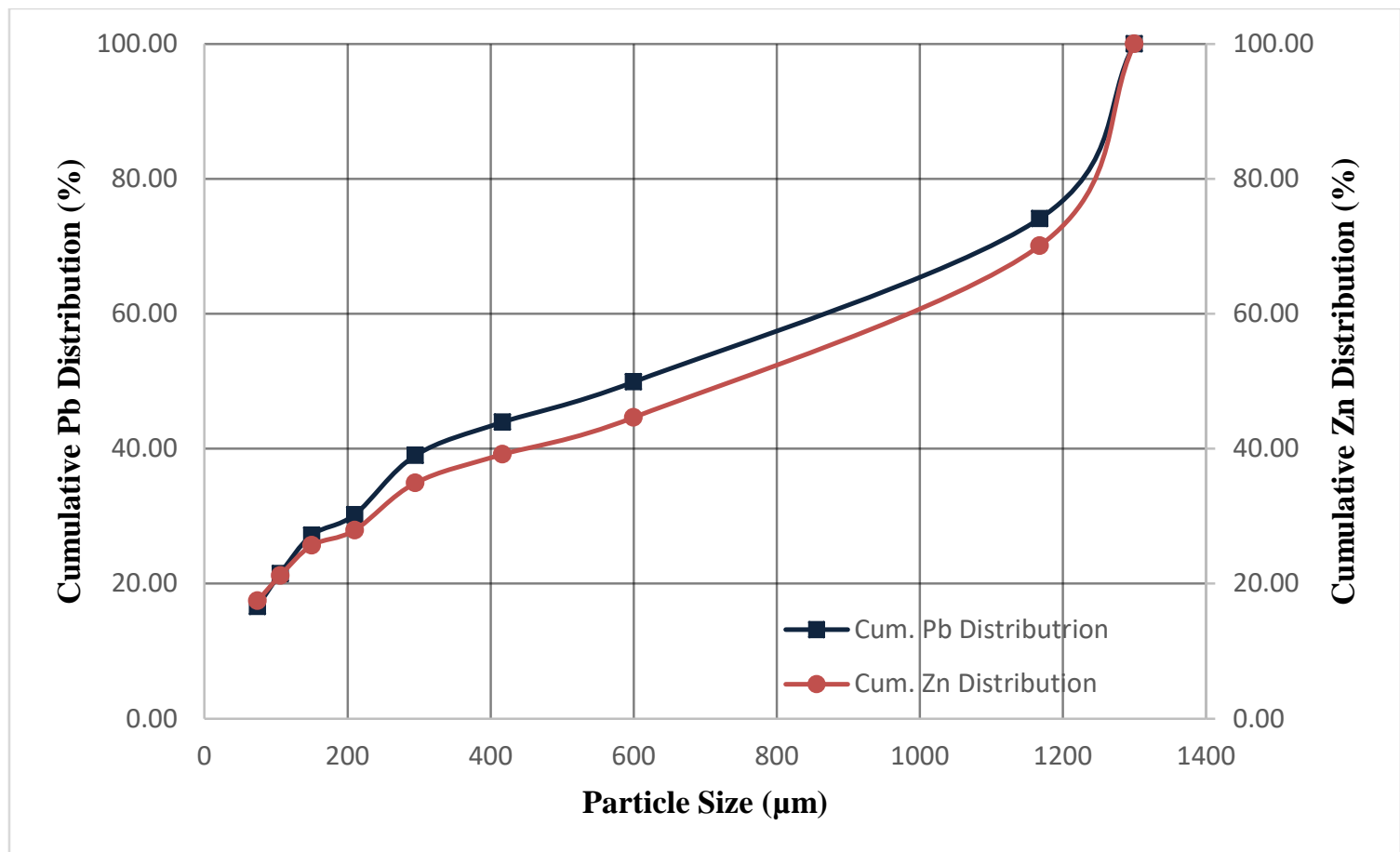

Fig. 1: Cumulative metal distribution of the representative sample.

\subsection{Method}

The experimental procedure followed during this study is presented in Fig. 2.

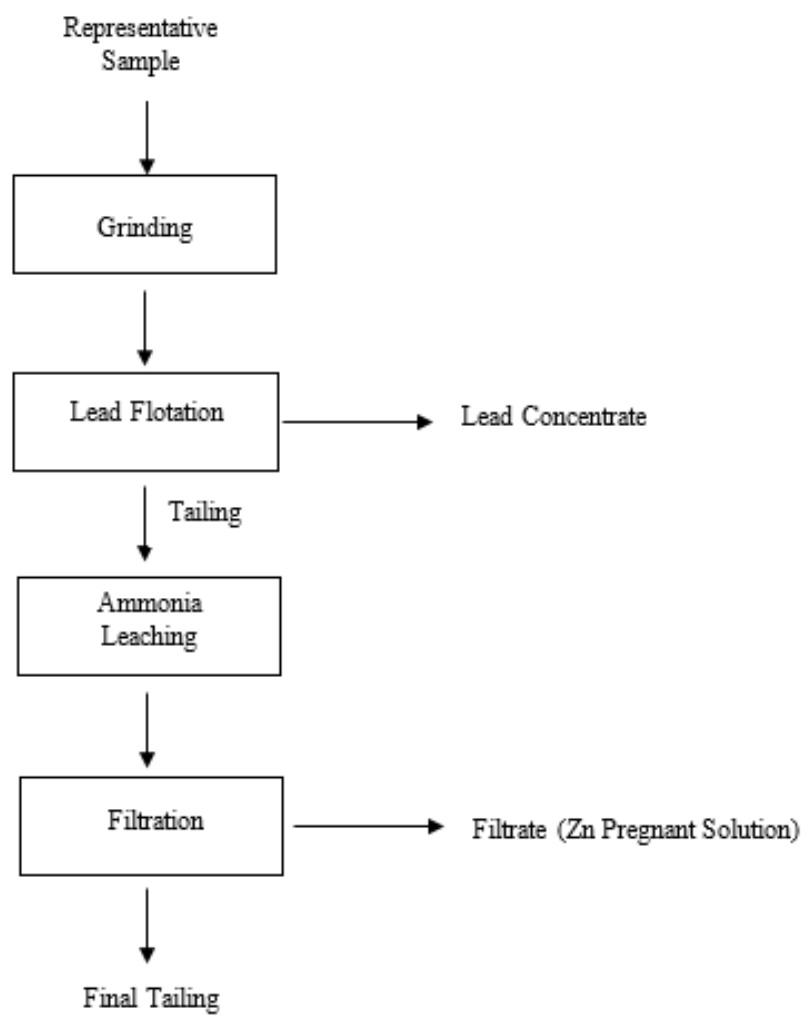

Fig. 2: Flowsheet of the study. 
First grinding tests were carried out. The test material was ground for 5, 10 and 15 minutes in a rod mill and then sieve analysis was applied to ground material. 10 minutes of grinding was decided to be used for the rest of the study and with this grinding condition, approximately $97 \%$ of the material was $-75 \mu \mathrm{m}$. Lead flotation tests were performed using Denver flotation cell with $30 \%$ solid by weight pulp density. Optimum flotation parameters for this lead concentration were determined by a series of flotation tests with examining several flotation parameter such as effect of amount and conditioning time of sulfidizing agent, collector type and amount, desliming and $\mathrm{pH}$. As a result of these tests, as sulfidizer $2000 \mathrm{~g} / \mathrm{t} \mathrm{Na} 2 \mathrm{~S}$ with 10 minutes of conditioning, as collector $400 \mathrm{~g} / \mathrm{t}$ potassium amyl xanthate (KAX) and as frother $53 \mathrm{~g} / \mathrm{t}$ F-533 (mixture of alcohols, esters and glycols) at pH 9-9.5 with one stage cleaning were determined as optimum conditions for the study.

In the second part, tailings of lead flotation were tried to be floated to obtain $\mathrm{Zn}$ concentrate but due to finely and disseminated $\mathrm{Zn}$ particles, smithsonite flotation tests were not successful in terms of grade and recovery despite many tests conducted by changing various operational parameters. For that reason ammonia leaching was decided to be performed for tailings of lead flotation. Within the context of leach experiments, $5 \mathrm{M}$ and $7 \mathrm{M}$ of $\mathrm{NH} 3$ solutions were prepared and samples were treated for various leaching durations $\left(30,60,180,360\right.$ and 720 minutes) at ambient temperature $\left(\sim 25^{\circ} \mathrm{C}\right)$. Solid/liquid ratio was taken as 1:10 during all leaching tests. At the end of each leach test, solutions were filtered and both filtrate and residues were analysed using Atomic Absroption Spectroscopy (AAS). Examined parameters during leaching tests are presented in Table 3 and the reaction takes place during the process is given in Equation 1.

Table 3: Examined test parameters.

\begin{tabular}{|c|c|c|}
\hline Leaching Reagent & Concentration (M) & Leaching Duration (min.) \\
\hline $\mathbf{N H}_{3}$ & 5 & $30,60,180,360,720$ \\
\hline $\mathbf{N H}_{3}$ & 7 & $30,60,180,360,720$ \\
\hline \multicolumn{2}{|c}{$\mathrm{ZnCO}_{3(\mathrm{~s})}+4 \mathrm{NH}_{3(\mathrm{aq})} \leftrightarrow \mathrm{Zn}\left(\mathrm{NH}_{3}\right)_{4}{ }_{(\text {(aq) }}+\mathrm{CO}_{3}{ }^{2-}$} \\
\hline
\end{tabular}

\section{Results and Discussion}

From the results it can be concluded that both $\mathrm{NH}_{3}$ concentration and leaching duration have considerable importance on $\mathrm{Zn}$ extraction rate. Increase in reagent concentration causes sharp increase in extraction rate up to 180 minutes durations. Additionally longer leaching durations resulted with increase in extraction rate of $\mathrm{Zn}$.

Even the maximum recovery result was obtained using $7 \mathrm{M} \mathrm{NH}_{3}$ with 720 minutes of treatment, $7 \mathrm{M}$ concentration and 360 minutes duration is also viable. On the other hand extraction rate results of $5 \mathrm{M}$ for 360 and 720 minutes must also be considered since using $5 \mathrm{M}$ of solution would reduce reagent consumption. The results of the experiments are given in Table 4 and graphical representation is provided in Fig. 3.

Table 4: Effect of reagent concentration and leaching duration on $\mathrm{Zn}$ extraction rate.

\begin{tabular}{|c|c|c|c|c|c|c|}
\hline \multirow{2}{*}{ Leaching Reagent } & \multirow{2}{*}{ Concentration (M) } & \multicolumn{4}{|c|}{$\begin{array}{c}\text { Leaching Time (min.) } \\
\text { Zn Extraction (\%) }\end{array}$} \\
\cline { 3 - 7 } & & $\mathbf{3 0}$ & $\mathbf{6 0}$ & $\mathbf{1 8 0}$ & $\mathbf{3 6 0}$ & $\mathbf{7 2 0}$ \\
\hline $\mathrm{NH}_{3}$ & 5 & 25.79 & 32.40 & 59.42 & 72.77 & 75.04 \\
\hline $\mathrm{NH}_{3}$ & 7 & 35.63 & 49.75 & 66.37 & 74.30 & 76.66 \\
\hline
\end{tabular}




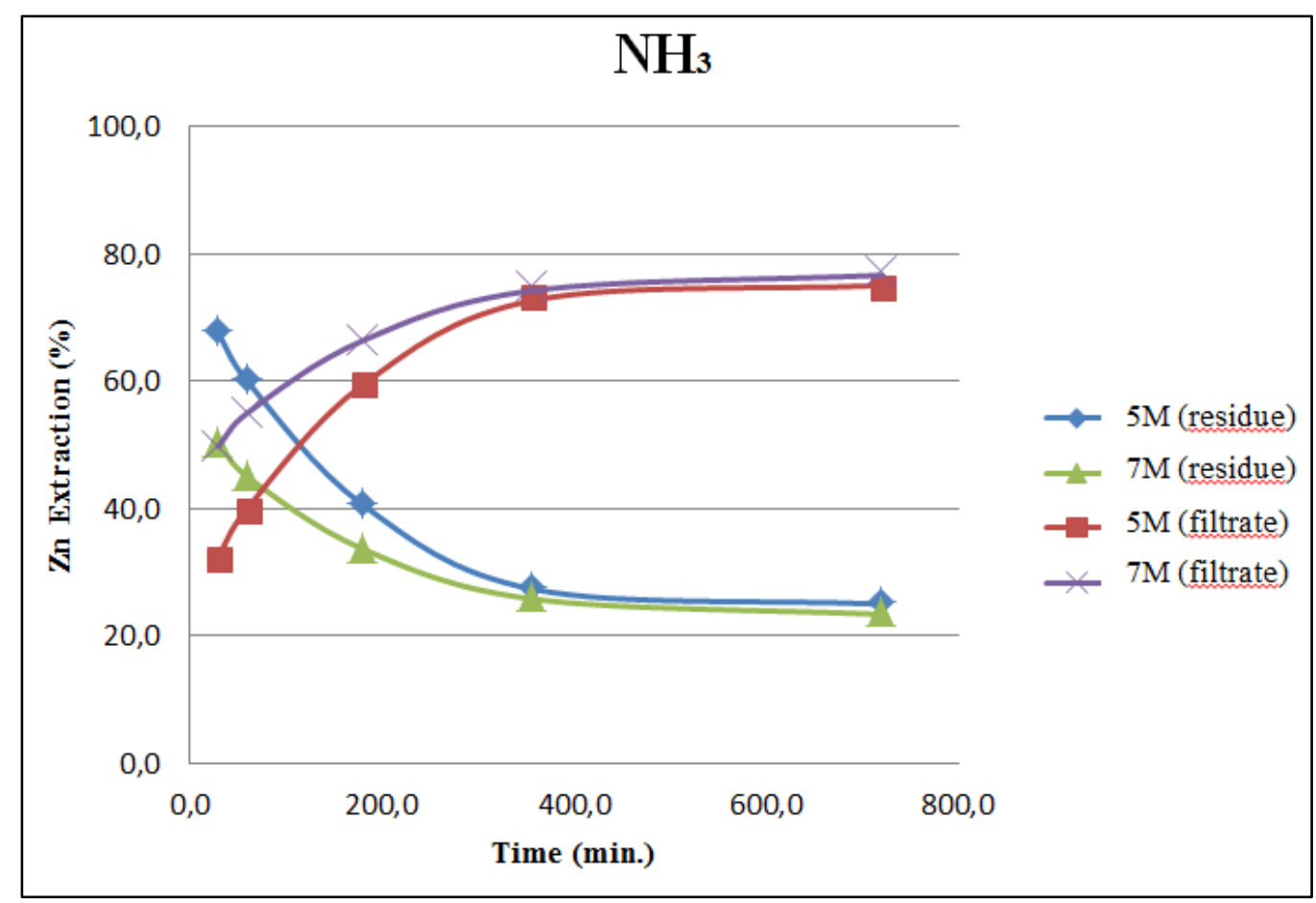

Fig. 3: Effect of $\mathrm{NH}_{3}$ concentration on $\mathrm{Zn}$ extraction with respect to leaching duration.

This study is progressing with different ammonia salts such as ammonium chloride $\left(\mathrm{NH}_{4} \mathrm{Cl}\right)$ or ammonium carbonate $\left(\left(\mathrm{NH}_{4}\right)_{2} \mathrm{CO}_{3}\right)$ to more comprehensively understand the leachability of smithsonite and to investigate the effect of different reagents on $\mathrm{Zn}$ extraction.

\section{Conclusions}

This study proves the suitability of ammonia $\left(\mathrm{NH}_{3}\right)$ for extraction of $\mathrm{Zn}$ from smithsonite obtained from Central Anatolia, Turkey. Within the scope of the study, $\mathrm{NH}_{3}$ was used for 5 and $7 \mathrm{M}$ concentrations and leaching duration was changed to see its effect on zinc extraction. Experiments revealed the positive effect of high ammonia concentration and longer leaching duration on extraction rate of $\mathrm{Zn}$. As leaching duration gets longer, extraction rate of zinc gets higher both for 5 and $7 \mathrm{M}$ concentrations. The maximum extraction rate was $76.66 \%$ using $7 \mathrm{M}$ of $\mathrm{NH}_{3}$ for 12 hours.

\section{References}

[1] M. Ejtemaei, M. Gharabaghi, M. Irannajad, "A Review of Zinc Oxide Mineral Beneficiation Using Flotation Method," Advances in Colloid and Interface Science, pp. 68-78, 2014.

[2] S. Moradi, A. Monhemius, "Mixed Sulfide-Oxide Lead and Zinc Ores: Problems and Solutions," Minerals Engineering, pp. 1062-1076, 2011.

[3] S. Ma, J. Yang, G. Wang, W. Mo, X. Su, "Alkaline Leaching of Low Grade Complex Zinc Oxide Ore,” Advanced Materials Research, pp. 12-17, 2011.

[4] E. Abkhoshk, E. Jorjani, M. S. Al-Harahsheh, F. Rashchi ve M. Naazari, "Review of Hydrometallurgical Processing of Non-Sulfide Zinc Ores," Hydrometallurgy, pp. 153-167, 2014.

[5] A. Gupta, D. Yan, Mineral Processing Design and Operation. Perth, 2006.

[6] B. Şentürk, Flotation of Lead-Zinc Carbonate Ore of Kayseri-Zamantı District. Ankara, 1987.

[7] F. Habashi, "Principles of Extractive Metallurgy," vol. 2, 1970.

[8] Z. Lan, D. Li, Q. Liu, X. Tong, "Study on Flotation of Lead-Zinc Oxide Ore from Yunnan," Advanced Materials Research, pp. 2317-2322, 2013.

[9] X. Meng, K. Han, "The Principles and Applications of Ammonia Leaching of Metals - A Review," Mineral Processing and Extractive Metallurgy Review, pp. 23-61, 1996. 
[10] S. Ju, T. Motang, Y. Shenghai, L. Yingnian, "Dissolution Kinetics of Smithsonite Ore in Ammonium Chloride Solution," Hydrometallurgy, pp. 67-74, 2005.

[11] Z. Liu, Z. Liu, Q. Li, Z. Cao, T. Yang, "Dissolution Behavior of Willemite in the (NH4)2SO4 - NH3 - H20 System," Hydrometallurgy, pp. 50-54, 2012.

[12] J. Moghaddam, R. Sarraf-Mamoory, Y. Yamini ve M. Abdollahy, "Determination of the Optimum Conditions for the Leaching of Nonsulfide Zinc Ores (High-SiO2) in Ammonium Carbonate Media," Ind. Eng. Chem. Res., pp. 8952-8958, 2005.

[13] R. Wang, M. Tang, S. Yang, W. Zhagn, C. Tang, J. He, J. Yang, "Leaching Kinetics of Low Garde Zinc Oxide Ore in NH3-NH4Cl-H2O System,” J. Cent. South Univ. Technology, pp. 679-683, 2008.

[14] M. Ejtemaei, M. Irannajad, M. Gharabaghi, "Influence of Important Factors on Flotation of Zinc Oxide Mineral Using Cationic, Anionic and Mixed (Cationic/Anionic) Collectors," Minerals Engineering, pp. 1402-1408, 2011.

[15] K. Fa, J. Miller, T. Jiang, G. Li, "Sulphidization Flotation for Recovery of Lead and Zinc from Oxide-Sulfide Ores," Trans. Nonferrous Met. Soc. China, pp. 1138-1144, 2005.

[16] B. Şentürk, G. Özbayoğlu, Ü. Atalay, "Kayseri Zamantı Bölgesi Karbonatlı Çinko-Kurşun Cevherinin Flotasyon ile Zenginleştirilmesi," \%1 içinde Türkiye XIII. Madencilik Kongresi, 1993.

[17] A. Mehdilo, M. Irannajad, H. Zarei, "Smithsonite Flotation from Zinc Oxide Ore Using Alkyl Amine Acetate Collectors," Separation Science and Technology, pp. 445-457, 2014.

[18] SOP, "Specialization Comission Metallic Mines Sub-Comisson Lead-Zinc-Cadmium Study Group Report," Ankara, 2011. Flotasyon ile Zenginleştirilmesi," \%1 içinde Türkiye XIII. Madencilik Kongresi, 1993.

[17] A. Mehdilo, M. Irannajad, H. Zarei, "Smithsonite Flotation from Zinc Oxide Ore Using Alkyl Amine Acetate Collectors," Separation Science and Technology, pp. 445-457, 2014.

[18] SOP, "Specialization Comission Metallic Mines Sub-Comisson Lead-Zinc-Cadmium Study Group Report," Ankara, 2011. 